\title{
Preclinical Evaluation of Antihyperglycemic Activity of Clerodendron infortunatum Leaf Against Streptozotocin-Induced Diabetic Rats
}

Sudipta Das · Sanjib Bhattacharya · Angelene Prasanna · R. B. Suresh Kumar • Goutam Pramanik · Pallab K. Haldar

Received: November 4, 2010 / Published online: February 8, 2011

(c) The Author(s) 2011. This article is published with open access at Springerlink.com

\section{ABSTRACT}

Introduction: Clerodendron infortunatum Linn. (Verbenaceae), commonly known as Bhant in Hindi, is a small shrub occurring throughout the plains of India, which is traditionally used for several medicinal purposes. The aim of the present study was to evaluate the preclinical antihyperglycemic activity of the methanol extract of the leaves of C. infortunatum (MECI) in Wistar rats. Methods: Hyperglycemia was induced in rats by a single intraperitoneal injection of streptozotocin (STZ, $65 \mathrm{mg} / \mathrm{kg}$ body weight). Three days after STZ induction, the hyperglycemic rats were treated with MECI intraperitoneally at the doses of 250 and $500 \mathrm{mg} / \mathrm{kg}$ body weight daily for 15 days.

Sudipta Das

Netaji Subhas Chandra Bose Institute of Pharmacy,

Nadia, India

Sanjib Bhattacharya

Bengal School of Technology, Hooghly, India

Angelene Prasanna · R. B. Suresh Kumar ·

Pallab K. Haldar $(\bowtie)$

Department of Pharmaceutical Technology,

Jadavpur University, Kolkata 700032, West Bengal, India.

Email: pallab_haldar@rediffmail.com

Goutam Pramanik

Bengal College of Pharmaceutical Science \& Research,

Durgapur, India
Glibenclamide $(0.5 \mathrm{mg} / \mathrm{kg}$, orally) was used as a reference drug. The fasting blood glucose levels were measured on every fifth day during the 15 days of treatment. Serum biochemical parameters such as glutamate pyruvate transaminase, glutamate oxaloacetate transaminase, alkaline phosphatase, cholesterol, and total protein were estimated. Antioxidant properties were assessed by estimating hepatic lipid peroxidation, reduced glutathione (GSH), and catalase (CAT). Results: MECI at the doses of 250 and $500 \mathrm{mg} / \mathrm{kg}$ intraperitoneally significantly $(P<0.001)$ and dose-dependently reduced and normalized blood glucose levels as compared to that of the STZ control group. Serum biochemical parameters were significantly $(P<0.001)$ restored towards normal levels in MECItreated rats as compared to the STZ control. MECI treatment also significantly $(P<0.001)$ decreased lipid peroxidation and recovered GSH levels and CAT activity towards normal values, as compared to the STZ control. Conclusion: The present study demonstrated that the leaves of $C$. infortunatum had remarkable preclinical antihyperglycemic activity in STZ-induced diabetic rats.

Keywords: antihyperglycemic; antioxidant; Clerodendron infortunatum; glibenclamide; streptozotocin 


\section{INTRODUCTION}

Diabetes mellitus is a chronic metabolic disorder of carbohydrate, lipid, and protein metabolism. It is characterized by hyperglycemia, glycosurea, hyperlipidemia, negative nitrogen balance, and sometimes ketonemia, due to insufficient or complete cessation of insulin synthesis, or secretion and/or peripheral resistance to insulin action. Diabetes is still not completely curable by current antidiabetic drugs. Insulin therapy is the only satisfactory approach in diabetes mellitus, even though it has several drawbacks, such as insulin resistance, anorexia, brain atrophy, and fatty liver, in chronic treatment. ${ }^{1}$ Treatment of patients with type 2 diabetes mellitus with oral hypoglycemic agents like sulfonylureas and biguanides, is always associated with side effects. $^{2}$ Therefore, herbal drugs are gaining popularity in the treatment of diabetes mellitus. The main benefits of herbal medicine seem to be their efficacy, low incidence of adverse effects, and low cost.

Clerodendron infortunatum Linn. (Verbenaceae), commonly known as Bhant in Hindi, is a small shrub occurring throughout the plains of India. This plant has been used in Indian folk medicine in the treatment of bronchitis, asthma, fever, burning sensation, diseases of the blood, inflammation, and epilepsy. ${ }^{3,4}$ Traditionally, the plant is used as an antipyretic and anthelmintic. Leaves of the plant are prescribed for tumors, certain skin diseases, and scorpion stings. ${ }^{5}$ Previous phytochemical investigation of the plant revealed the presence of alkyl sterols and 2,-(3,4-dehydroxyphenyl) ethanol 1-O- $\alpha-2$ rhamnopyranosyl- $(1 \rightarrow 3)-\beta-D-$ (4-O-caffeoyl) glycopyranoside or acteoside. ${ }^{6,7}$ Previous work has reported hepatoprotective, anti-inflammatory, antinociceptive, and neuropharmacological activities of $C$. infortunatum..$^{8-10}$ Until now, there have been no reports on antidiabetic investigations of this plant. The present study was therefore intended to investigate the preclinical antihyperglycemic effect of the methanol extract of the leaves of C. infortunatum (MECI) against streptozotocin (STZ)-induced diabetic Wistar rats.

\section{MATERIALS AND METHODS}

\section{Plant Material}

The leaves of $C$. infortunatum were collected in November 2008 from the forest region of Midnapore state, West Bengal, India. The plant species was authenticated at the Central National Herbarium, Botanical Survey of India, Howrah, West Bengal, India. The voucher specimen (no. PMU-4/JU/2008) has been preserved in the Pharmacology Research Laboratory, Jadavpur University, Kolkata, India for future reference. The leaves were dried under shade and then powdered using a mechanical grinder into a coarse powder.

\section{Preparation of Extract}

The powdered plant material was extracted with $80 \%$ methanol using Soxhlet extraction apparatus. The solvent was removed completely under reduced pressure and a semisolid mass was obtained (MECI, yield 13.5\% w/w). The extracts were stored in a vacuum desiccator for further use. Preliminary phytochemical screening of the MECI plant extract showed the presence of flavonoids, tannins, and saponins.

\section{Animals}

Adult male Wistar albino rats weighing 170-200 g were used for the present investigation. They were housed in a clean polypropylene cage and maintained under standard laboratory conditions 
(temperature $25 \pm 2^{\circ} \mathrm{C}$ with dark/light cycle $12 / 12 \mathrm{~h}$ ). They were fed a standard pellet diet (Hindustan Lever, Kolkata, India) and received water ad libitum. The animals were acclimatized to laboratory conditions for 1 week prior to the experiment. All experimental procedures described were reviewed and approved by the University Animal Ethics Committee, Jadavpur University.

\section{Drugs and Chemicals}

STZ, 5,5-dithio bis-2-nitro benzoic acid, reduced glutathione (GSH), and nitroblue tetrazolium were obtained from SISCO Research Lab, Mumbai, India; thiobarbituric acid and trichloroacetic acid were obtained from Merck, Mumbai, India; potassium dichromate and glacial acetic acid were obtained from Ranbaxy, Mumbai; glibenclamide was obtained from Hoechst, India. All other reagents used were of analytical grade and were obtained commercially.

\section{Induction of Diabetes}

Diabetes mellitus was induced in overnightfasted rats by a single intraperitoneal (i.p.) injection of STZ (65 mg/kg body weight [b.w.]). ${ }^{11}$ After 3 days, fasting blood glucose levels were measured and the animals showing blood glucose levels $\geq 225 \mathrm{mg} / \mathrm{dL}$ were used for the present investigation. ${ }^{12}$

\section{Treatment Schedule and Estimation of Fasting Blood Glucose Level}

The rats were divided into five groups $(n=6)$. Except for group I, which served as normal nondiabetic controls, all other groups consisted of diabetic rats. Group I received normal saline ( $5 \mathrm{~mL} / \mathrm{kg}$ b.w.). Group II served as diabetic (STZ) controls. Groups III and IV received MECI (250 and $500 \mathrm{mg} / \mathrm{kg}$ b.w., i.p., respectively), and group $\mathrm{V}$ received the reference drug, glibenclamide ( $0.5 \mathrm{mg} / \mathrm{kg}$ b.w., orally), daily for 15 days. Fasting blood glucose was measured on the days 0,5 , 10, and 15 using a one-touch glucometer (Accucheck) and the body weights of rats from each group were measured both before and 15 days after treatment. Twenty-four hours after the last dose, blood was collected from overnight-fasted rats from each group by cardiac puncture in order to estimate serum biochemical parameters. The rats were then killed by cervical dislocation for the study of liver biochemical parameters. ${ }^{13}$

\section{Estimation of Serum Biochemical Parameters}

Collected blood was used for the estimation of serum biochemical parameters viz. serum glutamate oxaloacetate transaminase (SGOT), serum glutamate pyruvate transaminase (SGPT), serum alkaline phosphatase (SALP), serum cholesterol, and total protein contents by using commercially available reagent kits (Span Diagnostics, Surat, India).

\section{Estimation of Liver Biochemical Parameters}

Lipid peroxidation, ie, thiobarbituric acid reactive substances (TBARS), was estimated by a previously reported method and expressed as millimoles per $100 \mathrm{~g}$ of tissue. ${ }^{14} \mathrm{GSH}$ was determined by a previously reported method and was expressed as milligrams per $100 \mathrm{~g}$ of tissue. ${ }^{15}$ Catalase (CAT) activity was assayed according to the method described earlier, and expressed as micromoles of hydrogen peroxide $\left(\mathrm{H}_{2} \mathrm{O}_{2}\right)$ consumed per minute per milligram of liver tissue. ${ }^{16}$

\section{Statistical Analysis}

The experimental results were expressed as mean \pm standard error of mean (SEM). Statistical 
significance was analyzed by one-way analysis of variance, followed by Dunnett's test using computerized Graph Pad InStat version 3.05, Graph pad software, USA. $P$ values of $<0.001$ were considered to be statistically significant.

\section{RESULTS}

\section{Fasting Blood Glucose}

The fasting blood glucose levels of normal, diabetic, and treated rats are summarized in Table 1 . STZ at the dose of $65 \mathrm{mg} / \mathrm{kg}$ produced marked hyperglycemia as evident from a significant $(P<0.001)$ elevation in fasting blood glucose level in the STZ control group as compared to the normal control group. Administration of MECI in STZ-induced diabetic rats at the doses of 250 and $500 \mathrm{mg} / \mathrm{kg}$ b.w. produced a significant $(P<0.001)$ and dosedependent decrease in blood glucose levels when compared with the STZ control group.

\section{Body Weight}

The body weight of rats from the STZ control group (after 15 days) was significantly $(P<0.001)$ decreased when compared with the normal control group. MECI at 250 and $500 \mathrm{mg} / \mathrm{kg}$ b.w. significantly $(P<0.001)$ increased body weight towards normal levels in a dose-dependent manner compared to the STZ control group (Table 2).

\section{Serum Biochemical Parameters}

Biochemical parameters such as SGOT, SGPT, SALP, and serum cholesterol in the STZ control group were significantly $(P<0.001)$ elevated as compared to the normal control group. Treatment with MECI at the doses of 250 and $500 \mathrm{mg} / \mathrm{kg}$ b.w. significantly $(P<0.001)$ changed the SGOT, SGPT, SALP, and serum cholesterol levels towards the normal values in a dosedependent manner. The total protein was found to be significantly decreased in the STZ control group as compared with the normal control group $(P<0.001)$. Administration of MECI in diabetic animals significantly $(P<0.001)$ increased the total protein content as compared with the STZ control group (Table 3).

\section{Liver Biochemical Parameters}

The levels of TBARS were significantly $(P<0.001)$ increased in STZ control animals as compared to

Table 1. Effect of the methanol extract of the leaves of Clerodendron infortunatum (MECI) on fasting blood glucose levels in hyperglycemic rats.

\begin{tabular}{lccccc}
\hline & \multicolumn{4}{c}{ Fasting blood glucose level $(\mathrm{mg} / \mathrm{dL})$} \\
\cline { 2 - 6 } Group & Dose & Day 0 & Day 5 & Day 10 & Day 15 \\
\hline I (Normal control) & $5 \mathrm{~mL} / \mathrm{kg}$ & $75.22 \pm 3.2$ & $74.32 \pm 2.3$ & $76.81 \pm 3.5$ & $78.40 \pm 1.7$ \\
II (STZ) & $65 \mathrm{mg} / \mathrm{kg}$ & $261.54 \pm 10.2^{*}$ & $275.35 \pm 9.8^{*}$ & $283.21 \pm 12.62^{*}$ & $296.72 \pm 10.6^{*}$ \\
III (STZ+MECI) & $250 \mathrm{mg} / \mathrm{kg}$ & $258.23 \pm 10.7$ & $145.58 \pm 8.6 \dagger$ & $112.45 \pm 2.4 \dagger$ & $96.42 \pm 2.5 \dagger$ \\
IV (STZ+MECI) & $500 \mathrm{mg} / \mathrm{kg}$ & $260.76 \pm 6.4$ & $97.37 \pm 3.4 \dagger$ & $86.22 \pm 2.1 \dagger$ & $75.52 \pm 3.8 \dagger$ \\
V (STZ+Gliben) & $0.5 \mathrm{mg} / \mathrm{kg}$ & $266.33 \pm 7.3$ & $95.96 \pm 6.8 \dagger$ & $84.33 \pm 3.4 \dagger$ & $74.56 \pm 3.5 \dagger$ \\
\hline
\end{tabular}

Values are expressed as mean \pm standard error of the mean $(n=6)$.

${ }^{*} P<0.001$ compared with normal control.

$+P<0.001$ compared with STZ control.

Gliben=glibenclamide; STZ=streptozotocin. 
Table 2. Effect of the methanol extract of the leaves of Clerodendron infortunatum (MECI) on the body weight of hyperglycemic rats.

\begin{tabular}{lccc}
\hline & & Initial body weight & Final body weight \\
\cline { 3 - 4 } Group & Dose & $(\mathrm{g})$ & $(\mathrm{g})$ \\
\hline I (Normal control) & $5 \mathrm{~mL} / \mathrm{kg}$ & $175.46 \pm 1.6$ & $178.36 \pm 4.6$ \\
II (STZ) & $65 \mathrm{mg} / \mathrm{kg}$ & $172.52 \pm 2.6$ & $148.21 \pm 2.3^{*}$ \\
III (STZ+MECI) & $250 \mathrm{mg} / \mathrm{kg}$ & $170.23 \pm 2.8$ & $154.61 \pm 2.5 \dagger$ \\
IV (STZ+MECI) & $500 \mathrm{mg} / \mathrm{kg}$ & $174.32 \pm 1.2$ & $151.62 \pm 1.2 \dagger$ \\
V (STZ+Gliben) & $0.5 \mathrm{mg} / \mathrm{kg}$ & $171.25 \pm 3.8$ & $159.76 \pm 2.8 \dagger$ \\
\hline
\end{tabular}

Values are expressed as mean \pm standard error of the mean $(n=6)$.

${ }^{*} P<0.001$ compared with normal control.

$\dagger P<0.001$ compared with STZ control group.

Gliben=glibenclamide; STZ=streptozotocin.

Table 3. Effect of the methanol extract of the leaves of Clerodendron infortunatum (MECI) on serum biochemical parameters in hyperglycemic rats.

\begin{tabular}{lcccccc}
\hline & & & & Total & & Serum \\
Group & Dose & \multicolumn{1}{c}{$\begin{array}{c}\text { SGOT } \\
\text { (IU/L) }\end{array}$} & \multicolumn{1}{c}{$\begin{array}{c}\text { SGPT } \\
(\mathrm{IU} / \mathrm{L})\end{array}$} & $\begin{array}{c}\text { serum protein } \\
(\mathrm{g} / \mathrm{dL})\end{array}$ & $\begin{array}{c}\text { SALP } \\
(\mathrm{U} / \mathrm{L})\end{array}$ & $\begin{array}{c}\text { cholesterol } \\
(\mathrm{mg} / \mathrm{dL})\end{array}$ \\
\hline I(Normal control) & $5 \mathrm{~mL} / \mathrm{kg}$ & $20.24 \pm 5.6$ & $23.62 \pm 4.7$ & $6.52 \pm 2.6$ & $171.22 \pm 12.0$ & $155.76 \pm 8.4$ \\
II (STZ) & $65 \mathrm{mg} / \mathrm{kg}$ & $36.5 \pm 4.2^{*}$ & $39.41 \pm 5.2^{*}$ & $3.41 \pm 1.7^{*}$ & $243.5 \pm 12.5^{*}$ & $224.5 \pm 12.4^{*}$ \\
III (STZ+MECI) & $250 \mathrm{mg} / \mathrm{kg}$ & $28.9 \pm 3.4 \dagger$ & $29.5 \pm 3.4 \dagger$ & $5.78 \pm 2.8 \dagger$ & $206.56 \pm 11.2 \dagger$ & $182.8 \pm 11.2 \dagger$ \\
IV (STZ+MECI) & $500 \mathrm{mg} / \mathrm{kg}$ & $22.5 \pm 3.5 \dagger$ & $24.62 \pm 3.5 \dagger$ & $6.60 \pm 3.8 \dagger$ & $177.6 \pm 14.9 \dagger$ & $159.54 \pm 10.3 \dagger$ \\
V (STZ+Gliben.) & $0.5 \mathrm{mg} / \mathrm{kg}$ & $22.34 \pm 2.4 \dagger$ & $25.32 \pm 3.6 \dagger$ & $6.23 \pm 3.45 \dagger$ & $174.82 \pm 10.6 \dagger$ & $162.21 \pm 11.2 \dagger$ \\
\hline
\end{tabular}

Values are expressed as mean \pm standard error of the mean $(n=6)$.

${ }^{*} P<0.001$ compared with normal control.

$+P<0.001$ compared with STZ control group.

Gliben=glibenclamide; SALP=serum alkaline phosphatase; SGOT=serum glutamate oxaloacetate transaminase;

SGPT = serum glutamate pyruvate transaminase; $S T Z=$ streptozotocin.

the normal control group. Treatment with MECI at 250 and $500 \mathrm{mg} / \mathrm{kg}$ b.w. significantly $(P<0.001)$ reduced the TBARS levels when compared with STZ control animals in a dose-related manner. The level of GSH was significantly $(P<0.001)$ depleted in the STZ control group as compared with the normal control group. Reduced GSH levels were found to be significantly and dose-dependently $(P<0.001)$ elevated towards normal levels on administration of MECI, as compared with the STZ control group. There was a significant $(P<0.001)$ reduction in CAT activity in the STZ control group compared with the normal group. Administration of MECI significantly $(P<0.001)$ recovered CAT activity towards normal levels when compared with STZ control animals (Table 4).

\section{DISCUSSION}

The present work was intended to study the antihyperglycemic activity of MECI in STZ-induced diabetic rats. The results of this study revealed that MECI at doses of 250 and $500 \mathrm{mg} / \mathrm{kg}$ b.w. significantly normalized elevated blood glucose levels and restored serum and liver biochemical parameters towards normal values. 
Table 4. Effect of methanol extract of Clerodendron infortunatum leaf (MECI) on liver biochemical parameters in hyperglycemic rats.

\begin{tabular}{lcccc}
\hline Group & Dose & $\begin{array}{c}\text { TBARS } \\
(\mathbf{m M} / \mathbf{1 0 0} \\
\text { wet liver tissue })\end{array}$ & $\begin{array}{c}\text { GSH } \\
(\mathbf{m g} / \mathbf{1 0 0} \mathbf{g} \\
\text { wet liver tissue })\end{array}$ & $\begin{array}{c}\text { CAT } \\
\left(\mu \mathbf{m o l ~ H}_{2} \mathrm{O}_{2}\right. \\
\text { consumed } / \mathbf{m i n} / \mathbf{m g} \\
\text { wet liver tissue })\end{array}$ \\
\hline I (Normal control) & $5 \mathrm{~mL} / \mathrm{kg}$ & $1.16 \pm 0.4$ & $43.32 \pm 1.5$ & $82.18 \pm 3.5$ \\
II (STZ) & $60 \mathrm{mg} / \mathrm{kg}$ & $2.05 \pm 0.3^{*}$ & $24.16 \pm 1.4^{*}$ & $45.38 \pm 4.1^{*}$ \\
III (STZ+MECI) & $250 \mathrm{mg} / \mathrm{kg}$ & $1.32 \pm 0.41 \dagger$ & $35.21 \pm 1.2 \dagger$ & $68.39 \pm 5.6 \dagger$ \\
IV (STZ+MECI) & $500 \mathrm{mg} / \mathrm{kg}$ & $1.18 \pm 0.52 \dagger$ & $40.12 \pm 1.1 \dagger$ & $78.42 \pm 3.8 \dagger$ \\
V (STZ+Gliben) & $0.5 \mathrm{mg} / \mathrm{kg}$ & $1.17 \pm 0.41 \dagger$ & $41.08 \pm 1.2 \dagger$ & $80.49 \pm 4.8 \dagger$ \\
\hline
\end{tabular}

Values are expressed as mean \pm standard error of the mean $(n=6)$.

${ }^{*} P<0.001$ compared with normal control.

$+P<0.001$ compared with STZ control group.

$\mathrm{CAT}=$ catalase; Gliben=glibenclamide; $\mathrm{GSH}=$ reduced glutathione; TBARS=thiobarbituric acid reactive substances;

STZ=streptozotocin.

STZ is an antibiotic obtained from Streptomyces achromogenes. It possesses diabetogenic properties mediated by pancreatic $\beta$-cell destruction, hence this compound has been widely used to induce diabetes mellitus in experimental animals. ${ }^{17}$ Once STZ enters cells, it undergoes spontaneous decomposition to form an isocyanate and a methyldiazohydroxide compound. The isocyanate and the methyldiazohydroxide compound cause intramolecular carboxylation and alkylation, respectively, of cellular components. ${ }^{18}$ The DNA damage to the pancreatic $\beta$ cells is mainly caused by alkylation with carbonium ions produced by the methyldiazohydroxide compound. ${ }^{19}$ STZ is not only damaging to the pancreatic $\beta$ cells, but it is also harmful to hepatocytes, nephrons, and cardiomyocytes. ${ }^{20}$

Hyperglycemia was observed after 3 days of STZ induction in the present study. Dosedependent treatment with MECI in STZinduced diabetic rats started to reduce fasting blood glucose levels after 5 days, leading to normoglycemic levels after 15 days. The antihyperglycemic effect of MECI at the $500 \mathrm{mg}$ / $\mathrm{kg}$ b.w. dose was found to be more effective and comparable to the effect exerted by the reference drug, glibenclamide, at the dose of $0.5 \mathrm{mg} / \mathrm{kg}$ b.w. MECI also showed a marked effect in controlling the loss of body weight in diabetic rats.

Elevation of serum hepatic biomarker enzymes, such as SGOT, SGPT, and SALP, was observed in diabetic rats, indicating impaired liver function, which may be due to hepatic damage. The decreased total protein content in STZ-induced animals also substantiated the hepatic damage caused by STZ. Diabetic complications, such as increased gluconeogenesis and ketogenesis, may be due to elevated transaminase activities. ${ }^{21}$ Fifteen days of treatment with MECI restored all the abovementioned parameters towards normal levels in a dose-dependent manner. It is well known that in uncontrolled diabetes mellitus there is an increase in total cholesterol present in blood, which may contribute to coronary artery diseases. ${ }^{22}$ In the present study, the elevated serum cholesterol levels in diabetic rats was normalized after treatment with MECI. This suggests that the extract may inhibit the pathway of cholesterol synthesis in diabetic rats.

Oxidative stress in diabetes mellitus has been shown to coexist with a reduction in the endogenous antioxidant status. ${ }^{23}$ Several sources 
of evidence suggest that STZ induces oxidative stress. ${ }^{17}$ Oxidative stress is caused by a relative overproduction of reactive oxygen species (ROS). ROS results in lipid peroxidation and, subsequently, increased TBARS levels, leading to degradation of cellular macromolecules. A marked increase in the concentration of hepatic TBARS in STZ-induced diabetic rats indicates enhanced lipid peroxidation, leading to tissue injury and failure of the antioxidant defense mechanisms to prevent overproduction of ROS. Lipid peroxidation is usually measured in terms of TBARS as a biomarker of oxidative stress. ${ }^{24}$ Treatment with META-inhibited hepatic lipid peroxidation in diabetic rats, as revealed by a reduction in TBARS levels towards normal values. This indicates the inhibition of freeradical generation in STZ-induced diabetic rats.

GSH plays an important role in the endogenous nonenzymatic antioxidant system. It acts primarily as a reducing agent and detoxifies hydrogen peroxide in the presence of an enzyme, glutathione peroxidase. ${ }^{25}$ The depleted GSH levels may be due to a reduction in GSH synthesis or degradation of GSH by oxidative stress in STZ-induced hyperglycemic animals. ${ }^{26}$ MECI treatment significantly elevated the depleted hepatic GSH levels towards normal values in diabetic rats. The results of the present study showed that the antihyperglycemic activity of MECI was accompanied by an enhancement in nonenzymatic antioxidant protection. These findings suggest that MECI may exert its antihyperglycemic effect through the enhancement of the cellular antioxidant system.

Enzymatic antioxidant mechanisms play an important role in the elimination of ROS. CAT is a heme-containing enzyme catalyzing the detoxification of hydrogen peroxide to water and oxygen. ${ }^{27}$ The inhibition of CAT activity as a result of STZ-induced hyperglycemia has been reported previously, and similar findings were observed in the present study. ${ }^{13,28}$ MECI treatment caused a significant recovery of CAT activity towards normal levels in a dose-dependent manner.

Diabetes mellitus is generally characterized by chronic, low-grade inflammation. ${ }^{29}$ Previous studies have confirmed the antiinflammatory efficacy of MECI. ${ }^{10}$ This property may be responsible for augmenting the antihyperglycemic potential of MECI and maintaining normalized parameters.

Preliminary phytochemical studies showed the presence of flavonoids, tannins, and saponins in MECI. Flavonoids and tannins are well-known polyphenolic natural antioxidants, which may be responsible for the antioxidant role of MECI. ${ }^{30}$

\section{CONCLUSION}

In the present study, administration of MECI to STZ-induced hyperglycemic rats demonstrated a prominent reduction in blood glucose levels and normalization of serum biochemical profiles when compared to STZ control rats. Also, MECI treatment resulted in significant modulation of lipid peroxidation, endogenous nonenzymatic (GSH) and enzymatic (CAT) antioxidant and detoxification systems. Therefore, it can be concluded that at the preclinical level, the methanol extract of the leaves of $C$. infortunatum is remarkably effective against STZ-induced diabetes in Wistar rats, plausibly due to its augmenting endogenous antioxidant mechanisms. It can be further inferred that $C$. infortunatum leaves may serve as an interesting candidate for the effective management of diabetes mellitus.

\section{ACKNOWLEDGMENTS}

The authors thank the authority of Jadavpur University, Kolkata 700032, India, for providing the necessary facilities to perform the present study. 
Pallab K. Haldar is the guarantor for this article, and takes responsibility for the integrity of the work as a whole.

Open Access. This article is distributed under the terms of the Creative Commons Attribution Noncommercial License which permits any noncommercial use, distribution, and reproduction in any medium, provided the original authors and source are credited.

\section{REFERENCES}

1. Piedrola G, Novo E, Escober F, Garcia-Robles R. White blood cell count and insulin resistance in patients with coronary artery disease. Ann Endocrinol. 2001;62:7-10.

2. Weidmann $P$, Boehlen LM, de Courten M. Pathogenesis and treatment of hypertension associated with diabetes mellitus. Am Heart J. 1993;125:1498-1513.

3. Nadkarni KM, Nadkarni AK. Indian Materia Medica. Bombay: Popular Publication; 2002.

4. Sreevastava N. Clerodendron and healthcare. J Med Aroma Plant Sci Biotech. 2007;1:142-150.

5. Chopra RN, Nayar SL, Chopra IC. Glossary of Indian Medicinal Plants. New Delhi: Publication and Information Directorate, CSIR; 1992.

6. Akihisa T, Matsubara Y, Ghosh P, Thakur S, Tamura T, Matsumoto T. Sterols of some Clerodendrum species (Verbenaceae): occurrence of the 24 alphaand 24 beta-epimers of 24-ethylsterols lacking a delta 25-bond. Steroids. 1989;53:625-638.

7. Sinha NK, Seth K, Pandey VB, Dasgupta B, Shah $\mathrm{AH}$. Flavonoids from the flowers of Clerodendron infortunatum. Planta Med. 1981;42:296-298.

8. Ahmed F, Shahid IZ, Biswas UK, Roy BA, Das AK, Choudhuri MSK. Anti-inflammatory, antinociceptive, and neuropharmacological activities of Clerodendron viscosum. Pharm Biol. 2007;45:587-593.

9. Sannigrahi S, Mazumder UK, Pal D, Mishra SL. Hepatoprotective potential of methanol extract of Clerodendrum infortunatum Linn. against CCl4 induced hepatotoxicity in rats. Phcog Mag. 2009;5:394-399.
10. Das S, Haldar PK, Pramanik G, Suresh RB. Evaluation of anti-inflammatory activity of Clerodendron infortunatum Linn. extract in rats. Global J Pharmacol. 2010;4:48-50.

11. Pellegrino MP, Broca C, Gross R, et al. Development of a new model of type II diabetes in adult rats administered with streptozotocin and nicotinamide. Diabetes. 1998;47:224-229.

12. Ewart RBL, Kornfeld S, Kipnis DM. Effect of lectins on hormone release from isolated rat islets of Langerhans. Diabetes. 1975;24,705-714.

13. Panda SP, Haldar PK, Bera S, Adhikary S, Kandar CC. Antidiabetic and antioxidant activity of Swietenia mahagoni in streptozotocin-induced diabetic rats. Pharm Biol. 2010;48:974-979.

14. Fraga CG, Leibovitz BE, Toppel AL. Lipid peroxidation measured as TBARS in tissue characterization and comparison with homogenates and microsomes. Free Radic Biol Med. 1981;4:155161.

15. Ellman GL. Tissue sulphydryl groups. Arch Biochem Biophys. 1959;82:70-77.

16. Sinha KA. Colorimetric assay of catalase. Annal Biochem.1972;47:389-394.

17. Junod A, Lambert AE, Stauffacher W, Renold AE. Diabetogenic action of streptozotocin: relationship of dose to metabolic response. J Clin Invest. 1969;48:2129-2139.

18. Varva JJ, DeBoer C, Dietz A. Streptozotocin, a new antibacterial antibiotic. Antibiot Annu. 19591960; 7:230-235.

19. Wright JR, Abraham C, Dickson BC, Yang H, Morrison CM. Streptozotocin dose response curve in tilapia, a glucose-responsive teleost fish. Gen Comp Endocrinol. 1999;114:431-440.

20. Frode TS, Medeiros YS. Animal models to test drugs with potential antidiabetic activity. J Ethnopharmacol. 2008;115:173-183.

21. Ghosh S, Suryawansi SA. Effect of Vinca rosea extracts in treatment of alloxan diabetes in male albino rats. Indian J Exp Biol. 2001;39:748-759.

22. Arvind K, Pradeep R, Deepa R, Mohan V. Diabetes and coronary artery diseases. Indian $\mathrm{J}$ Med Res. 2002;116:163-176.

23. Boynes JW. Role of oxidative stress in development of complication in diabetes. Diabetes. 1991;40:405411. 
24. Janero DR. Malondialdehyde and thiobarbituric acid reactivity as diagnostic indices of lipid peroxidation and peroxidative tissue injury. Free Rad Biol Med. 1990;9:515-540.

25. Arias IM, Jakoby WB. Glutathione: Metabolisms and Functions. New York: Raven Press; 1976.

26. Loven D, Schedf $\mathrm{H}$, Wilson $\mathrm{H}$, et al. Effect of insulin and oral glutathione on glutathione level and superoxide dismutase activities in organs of rats with streptozotocin induced diabetes. Diabetes. 1986;35:503-507.

27. Venukumar MR, Latha MS. Antioxidant activity of Curculigo orchioides in carbon tetrachloride induced hepatopathy in rats. Indian J Clin Biochem. 2002;17:80-87.

28. Sabu MC, Kuttan R. Antidiabetic activity of Aegle marmelos and its relationship with its antioxidant properties. Indian J Physiol Pharmacol. 2004;48:8188.

29. Thomann R, Rossinelli N, Keller U, et al. Differences in low-grade chronic inflammation and insulin resistance in women with previous gestational diabetes mellitus and women with polycystic ovary syndrome. Gynecol Endocrinol. 2008;24:199-206.

30. Pietta PG. Flavonoids as antioxidants. J Nat Prod. 2000;63:1035-1042. 